\title{
Forward Unbiasedness in the Short End of the Interest Rate Market
}

\author{
Samih Antoine Azar ${ }^{1}$ \\ ${ }^{1}$ Full Professor, Faculty of Business Administration \& Economics, Haigazian University, Mexique Street, \\ Kantari, Beirut, Lebanon \\ Correspondence: Samih Antoine Azar, Full Professor, Faculty of Business Administration \& Economics, \\ Haigazian University, Mexique Street, Kantari, Beirut, Lebanon. \\ Received: December 12, 2017 \\ Accepted: December 29, 2017 Online Published: January 8, 2018 \\ doi:10.5539/ibr.v11n2p70 \\ URL: https://doi.org/10.5539/ibr.v11n2p70
}

\begin{abstract}
Forward rate unbiasedness postulates that the forward rate is an unbiased estimator or predictor of the future spot rate. This case of risk neutrality has been tested extensively especially in the foreign exchange market. This paper departs from this line of research and studies unbiasedness at the short end of the interest rate market. Although, a priori, an investment of 6 months and an investment of three months rolled over for an additional 3 months are commonly believed to be riskless at first approximation, our results show otherwise. The precision of our estimators unveil a small but statistically significant risk premi um. The latter has two components, a constant risk premium and a time-variable one. The constant risk premium is estimated to be 14.4 basis points. The time-variable risk premium ranges between a maximum of 184.6 basis points, and a minimum of -123.2 basis points, and averages 5.4 basis points. The methodology in this paper is amenable and adaptable, with little adjustments, to other maturities. This is an agenda for the future.
\end{abstract}

\section{JEL Codes: E43, G12, G14, C22}

Keywords: unbiasedness, short term, interest rate market, neutrality, risk

\section{Introduction}

The expectations theory of the term structure of interest rates is known at least since the 1930s (Fisher, 1930; Keynes 1930). In its "pure" form it states that the long interest rate is an average of expected sho rt term interest rates. This implies that the forward rate is an unbiased predictor of the future rate. This has also been called forward market efficiency. The basic tenet is that there is no risk premium, whether constant or time-variable. Unfortunately the unbiasedness of interest rates has not been researched well enough. Most studies apply the expectations theory on currency markets (see the references below). This paper will test forward market efficiency in the interest rate market, specifically between an investment for 6 months and an investment for 3 months, i.e. between the 6-month US T-bill rate and the 3-month US T-bill rate. Since the data is overlapping the residuals from a regression of the forward rate on the expected future rate are auto-correlated. As Verbeek (2012) suggests, a way out of this problem is to apply Newey-West heteroscedasticity and autocorrelation (HAC) standard errors and covariance.

The expectations theory states that the long rate is proportional to the equally weighted expected series of short term rates, where $E_{0}$ is the expectation operator for the information set at time 0 (i.e. today) (Azar, 2018):

$$
\begin{gathered}
1+r l_{k}=\left[\left(1+r s_{0}\right)\left(1+E_{0}\left(r s_{1}\right)\right)\left(1+E_{0}\left(r s_{2}\right)\right)\left(1+E_{0}\left(r s_{3}\right)\right) \ldots\left(1+E_{0}\left(r s_{k-1}\right)\right)\right]^{1 / k} \\
=\left(1+r s_{0}\right)\left[\prod_{j=1}^{k-1}\left(+E_{0}\left(r s_{j}\right)\right)\right]^{\frac{1}{k-1}}
\end{gathered}
$$

where $r l_{k}$ is the long rate with a maturity $k$, and $r s_{t}$ is the short rate with maturity $1<k=$ an integer. If $r s$ is a random walk, then $E_{0}\left(r s_{j}\right)=r s_{0}$, for $j=1 \rightarrow(k-1)$, and equations (1) and (2) become (with conditionality):

$$
E_{0}\left(r l_{k}\right)=\left(\left[1+r s_{0}\right]\left[1+r s_{0}\right]^{k-1}\right)^{1 / k}-1=r s_{0} \Rightarrow r l_{k}=r s_{0}+\epsilon
$$

where $\epsilon$ is a stationary white noise process, having a mean of zero, if the pure expectations theory holds, and 
having a mean $\theta$ if there is a stationary and constant risk or liquidity premium, and having a mean of $\theta_{k}$ if the premium depends on the maturity $k$. Other forms of premiums are also consistent with the equation. For example, the value $\theta_{k}$ can be time-variable, and possibly auto-correlated.

Equation (3), which states that the spread between long and short rates is stationary in distribution, has been tested by Campbell and Shiller (1987), Shiller (1989), Campbell and Shiller (1991), Choi and Mohar (1991), Hall et al. (1992), Hejazi et al. (2000), Longstaff (2000), Bekaert and Hodrick (2001), Thorton (2005, 2006), Konstantinou (2005), Sarno et al. (2007), Mills and Markellos (2008), Suardi (2010), Finlay and Jones (2011), and Strohsal and Weber (2014) with mixed results. Most papers find that the highly reputable expectations theory does not deserve its renown.

Usually equation (1) is linearized, by assuming $\log (1+x) \approx x$ for small $x$ near zero, or else continuously compounded interest rates are utilized:

$$
\begin{aligned}
{\left[\log \left(1+r l_{k}\right)\right]=} & \log \left[\left(1+r s_{0}\right)\left(1+E_{0}\left(r s_{1}\right)\right)\left(1+E_{0}\left(r s_{2}\right)\right) \ldots\left(1+E_{0}\left(r s_{k-1}\right)\right)\right]^{1 / k} \approx r l_{k} \\
& \approx(1 / k)\left(r s_{0}+E_{0} r s_{1}+E_{0} r s_{2}+\cdots+E_{0} r s_{k-1}\right)
\end{aligned}
$$

After that, $r s_{o}$ is brought to the left hand side of the equation resulting in the following specification (with conditionality):

$$
E_{0}\left(r l_{k}-r s_{0}\right)=\frac{1}{k} E_{0}\left[\sum_{i=1}^{k-1} \sum_{j=1}^{j=i} \Delta r s_{j}\right]
$$

If $r s$ is a random walk then the above collapses to:

$$
r l_{k}-r s_{0}=\epsilon
$$

where $\epsilon$ is a stationary white noise process having a mean zero, if the pure expectations theory holds, having a mean of $\theta$ if there is a stationary and constant risk or liquidity premium, and having a mean of $\theta_{k}$ if the premium depends on the maturity $k$. Other forms of premiums are also consistent with the equation. For example, the value $\theta_{k}$ can be time-variable, and possibly auto-correlated.

The paper is organized as follows. In the next section, section 2 , the theory is presented and analyzed. The section includes some recent literature on the unbiasedness hypothesis. Section 3 is the empirical part. The last section summarizes and concludes.

\section{Theory}

We denote by $F_{t}$ the forward interest rate calculated at time $t$ for a maturity that starts at time $t+1$, equal to 3 months, and that matures at time $t+2$, i.e. in 6 months. Let $S_{t+1}$ be the actual yield, i.e. the quarterly T-bill rate, that will be observed in 3 months, and let the expectation operator be $E_{t}$ for the information set at time $t$, i.e. today. Then in case of risk neutrality and no arbitrage:

$$
E\left[S_{t+1}\right]=F_{t} \Rightarrow S_{t+1}=E\left[S_{t+1}\right]+\epsilon_{t+1}=F_{t}+\epsilon_{t+1}
$$

The last term on the right-hand side of equation (4) is akin to a simple regression with an intercept equal to zero, and a slope equal to +1 . If there is a constant risk premium $\rho$ then we have (Fama, 1984):

$$
E\left[S_{t+1}\right]-\rho=F_{t} \Rightarrow S_{t+1}=F_{t}-\rho+\epsilon_{t+1}
$$

In case the risk premium has two components: a time-variable premium and a constant risk premium, then we have:

This is equivalent to:

$$
E\left[S_{t+1}\right]-\rho_{t}-\alpha=F_{t} \Rightarrow S_{t+1}=-\alpha+F_{t}-\rho_{t}+\epsilon_{t+1}
$$

$$
S_{t+1}-F_{t}=-\alpha-\rho_{t}+\epsilon_{t+1}
$$

The time-variable risk premium is assumed to be known at time $t$. If not the ex post time-variable risk premium $\rho_{t+1}$ will replace $\rho_{t}$. In addition if $\rho_{t+1}$ is forecastable we will replace $\rho_{t}$ by $E_{t}\left(\rho_{t+1}\right)$. As a matter of fact $\rho_{t+1}$ will be found to be predictable by a parsimonious Box-Jenkins ARMA model. Finally, if there is a time-variable risk premium that is correlated with the forward rate, then we have:

$$
S_{t+1}=-\alpha+\beta F_{t}-\rho_{t}+\epsilon_{t+1} \quad \text { with } \beta>0
$$

Testing forward rate unbiasedness, or in other terms forward market efficiency, has benefited strongly from the advent of cointegration techniques. At the same time data on foreign exchange rates and forward exchange rates 
became available and cleaner. For the literature before the advent of cointegration the reader is referred to MacDonald (1988). The new cointegration techniques allowed a shift of the research from being a regression of the expected depreciation on the forward premium, or on the interest rate differential, to a regression in log-levels whereby the log of the level of the future spot rate is checked for cointegration with the lagged forward rate. Initially the econometric results were supportive of the unbiasedness hypothesis (Baillie and Bollerslev, 1989). The tests by these authors are relatively robust since they use pooled or panel data which multiplies the degrees of freedom and avoid small sample bias. Other authors found a bias in the forecast equation which forces the intercept to be zero and the slope to be +1 . However, lately the literature has shifted to two new specifications for the risk premium to explain the bias. One specification is non-linearities in the deviation from Uncovered Interest Parity ${ }^{1}$ (UIP) (Sarno et al., 2006), or the presence of endogenous structural breaks (Hatemi-J and Roca, 2012), or the parting of the variables between permanent and transitory components (Al-Zouby, 2010). Another approach is to test a joint hypothesis whereby the contemporaneous spot rate is cointegrated with the forward rate, and the other whether the forward rate is an optimal predictor of the future spot rate. The former hypothesis is implied by the random walk behavior of the spot exchange rate (McMillan, 2005). Finally there was an attempt to model the risk premium as a non-stationary process which implies a paradox. One cannot find cointegration between the forward rate and the future spot rate, and a cointegration between the forward rate, the risk premium, and the future spot rate (Kellard et al., 2001). This paradoxical effect is reconciled with theory only by assuming that the risk premium is stationary.

\section{Empirical Analysis}

First, the data is tested for unit roots. The unit root test that is selected is the KPSS test (Kwiatkowski et al, 1992). This test has the null of stationarity, and, compared to other tests, does not bias the results by over-rejecting the null hypothesis of stationarity. The quarterly and the semi-annual T-bill yields, together with the forward rate, follow all three a non-stationary distribution which dissipates in first-differences. The spread between the realized actual rate and the forward rate is stationary in distribution. Finally the ex post risk premium, which is the difference between the yield on an investment for 3 months rolled over for another 3 months, and the yield for an investment for six months, is also stationary. It must be mentioned that the rates for these two investments reject individually stationarity. This is more evidence that the ex post risk premium is stationary in distribution because the holding two period returns are non-stationary but are cointegrated, and have a stationary spread. All test results are available from the author upon request.

There are three consecutive panels in Table 1, which is captioned by the term "level regressions." All three panels are divided into 5 parts. The first part is fitting an Autoregressive Distributed Lag model, known as ARDL. The second part is estimating by Ordinary Least Squares (OLS) the same model with Newey-West heteroscedasticity and autocorrelation (HAC) standard errors and covariance (Newey-West and OLS, DOLS, and Canonical Cointegrating Regression, CCR. Each panel studies one version: regression of the 3-month Treasury bill yield on the forward rate for the period three months ahead, including in the regression the ex post risk premium, and running a regression of a model of the holding return on an investment for 3 months rolled over another 3 months on the holding return of an investment for 6 months. The ex post risk premium is modeled as the rolling premium, i.e. the difference in the holding return of a 6-month investment and a rolled over investment of 3 months. The 3-month return is the quarterly US T-bill yield, and the 6-month return is the 6-month US T-bill yield.

The ARDL regressions that are reported are for the long run impacts. One advantage of ARDL is that it does not impose the same lag length for all exogenous variables. In addition it permits the inclusion of dynamic regressors and fixed regressors. The dynamic regressor are non-stationary while the fixed regressors are the stationary variables. The first ARDL model, between the 3-month T-bill and the forward rate, is peculiar for three reasons. The first is that the constant is statistically insignificantly different from zero, while in the other four models the constant is negative and statistically highly significant. The constant is a measure of the constant risk premium. Second, the slope on the forward rate is +1 by inferential statistics. One would expect a bias. Third, the F-bounds test fails to reject the null hypothesis of no-cointegration, although the residual-based tests of Engle and Granger and of Phillips and Ouliaris reject this null. Overall one can conclude that this ARDL model is not satisfactory, casting doubts on the validity of the underlying model which is the risk-neutral unbiasedness hypothesis. The results of estimating the same model with OLS, and using Newey-West standard errors, are not favorable to the

\footnotetext{
${ }^{1}$ Uncovered Interest Parity is defined as the excess return between the change in the expected future exchange rate and the forward premium. Sometimes the forward premium is replaced by the differential in interest rates between domestic and foreign markets.
} 
assumption of risk neutrality either, although the slope on the forward rate is insignificantly different from +1 , having an actual t-stat of -0.1271 . The reason for rejecting neutrality is that the constant is negative, as expected, and is highly significant statistically. This constant risk premium is -0.1956 , or 19.56 basis points. This model also produces some peculiarities when the 3 cointegration techniques are applied to the data. All three find a statistically significant constant risk premium, having the expected negative sign. This risk premium is estimated by the three aforementioned techniques: -0.3246 (FMOLS), -0.3388 (DOLS), and -0.3247 (CCR). However these three estimates are higher than the single OLS estimate of -0.1956 . Another peculiarity is that the slope on the forward rate is found to be significantly greater than +1 , at the $5 \%$ one-tailed test. The critical $t$-statistic is 1.645, while the actual t-statistics are 1.6775 (FMOLS), 2.5308 (DOLS), and 1.6773 (CCR). Granted these two peculiarities the unbiasedness hypothesis under risk neutrality is rejected.

Table 1. Level regressions: (1) unbiasedness without a variable risk premium, (2) unbiasedness with the inclusion of the actual realized variable risk premium, and (3) relation between the 6-month holding period rate and the 3-month holding period rate rolled over another three months

\begin{tabular}{|c|c|c|c|c|c|c|c|}
\hline $\begin{array}{l}\text { Econometric } \\
\text { procedure }\end{array}$ & $\begin{array}{l}\text { Dependent } \\
\text { variable }\end{array}$ & $\begin{array}{l}\text { Independent } \\
\text { variable(s) }\end{array}$ & constant & slope & Slope $=1$ & $\begin{array}{l}\text { Coefficient } \\
\text { on risk } \\
\text { premium }\end{array}$ & $\begin{array}{l}\text { Cointegration } \\
\text { test(s) }\end{array}$ \\
\hline $\operatorname{ARDL}(3,0)$ & $\begin{array}{l}\text { Actual } \\
\text { 3-month } \\
\text { T-bill yield }\end{array}$ & $\begin{array}{l}\text { Forward } \\
\text { interest rate }\end{array}$ & $\begin{array}{c}0.093917 \\
(0.258987)\end{array}$ & $\begin{array}{c}0.933144 \\
(13.82778)\end{array}$ & $(-0.990709)$ & & $\begin{array}{ll}\text { F-bounds test: } \\
2.782906 \\
(>10 \%)\end{array}$ \\
\hline $\begin{array}{l}\text { OLS with } \\
\text { HAC } \\
\text { correction }\end{array}$ & $\begin{array}{l}\text { Actual } \\
\text { 3-month } \\
\text { T-bill yield }\end{array}$ & $\begin{array}{l}\text { Forward } \\
\text { interest rate }\end{array}$ & $\begin{array}{l}-0.195635 \\
(-6.12048)\end{array}$ & $\begin{array}{c}0.995875 \\
(30.67211)\end{array}$ & $(-0.12705)$ & - & $\begin{array}{l}\text { Engle-Granger: } \\
0.0000 \\
\text { Phillips-Ouliaris : } \\
0.0000\end{array}$ \\
\hline FMOLS & $\begin{array}{l}\text { Actual } \\
\text { 3-month } \\
\text { T-bill yield }\end{array}$ & $\begin{array}{l}\text { Forward } \\
\text { interest rate }\end{array}$ & $\begin{array}{c}-0.324568 \\
(-3.836930)\end{array}$ & $\begin{array}{c}1.024766 \\
(69.41095)\end{array}$ & (1.677463) & & \\
\hline DOLS & $\begin{array}{l}\text { Actual } \\
\text { 3-month } \\
\text { T-bill yield }\end{array}$ & $\begin{array}{l}\text { Forward } \\
\text { interest rate }\end{array}$ & $\begin{array}{c}-0.338803 \\
(-5.463163)\end{array}$ & $\begin{array}{c}1.027428 \\
(94.80206)\end{array}$ & $(2.530861)$ & & \\
\hline CCR & $\begin{array}{l}\text { Actual } \\
\text { 3-month } \\
\text { T-bill yield }\end{array}$ & $\begin{array}{l}\text { Forward } \\
\text { interest rate }\end{array}$ & $\begin{array}{c}-0.324680 \\
(-3.835774)\end{array}$ & $\begin{array}{c}1.024765 \\
(69.40601)\end{array}$ & (1.677282) & & \\
\hline $\operatorname{ARDL}(2,0)$ & $\begin{array}{l}\text { Actual } \\
\text { 3-month } \\
\text { T-bill yield }\end{array}$ & $\begin{array}{l}\text { Forward } \\
\text { interest rate } \\
\text { Risk } \\
\text { premium } \\
\end{array}$ & $\begin{array}{c}0.134615 \\
(1.013893)\end{array}$ & $\begin{array}{c}0.984644 \\
(45.61949)\end{array}$ & $(-0.711453)$ & $\begin{array}{c}-0.490914 \\
(-18.00425)\end{array}$ & $\begin{array}{l}\text { F-bounds test: } \\
29.43338(<1 \%)\end{array}$ \\
\hline $\begin{array}{l}\text { OLS with } \\
\text { HAC } \\
\text { correction }\end{array}$ & $\begin{array}{l}\text { Actual } \\
\text { 3-month } \\
\text { T-bill yield }\end{array}$ & $\begin{array}{l}\text { Forward } \\
\text { interest rate } \\
\text { Risk } \\
\text { premium }\end{array}$ & $\begin{array}{c}-0.122518 \\
(-1.623296)\end{array}$ & $\begin{array}{c}0.997484 \\
(46.10641)\end{array}$ & $(-0.116298)$ & $\begin{array}{c}-0.736364 \\
(-4.284654)\end{array}$ & $\begin{array}{l}\text { Engle-Granger: } \\
0.0000 \\
\text { Phillips-Ouliaris: } \\
0.0000\end{array}$ \\
\hline FMOLS & $\begin{array}{l}\text { Actual } \\
\text { 3-month } \\
\text { T-bill yield }\end{array}$ & $\begin{array}{l}\text { Forward } \\
\text { interest rate } \\
\text { Risk } \\
\text { premium } \\
\end{array}$ & $\begin{array}{c}-0.247852 \\
(-4.475624)\end{array}$ & $\begin{array}{c}1.022904 \\
(106.5194)\end{array}$ & (2.385073) & $\begin{array}{c}-0.723677 \\
(-11.27735)\end{array}$ & \\
\hline DOLS & $\begin{array}{l}\text { Actual } \\
\text { 3-month } \\
\text { T-bill yield }\end{array}$ & $\begin{array}{l}\text { Forward } \\
\text { interest rate } \\
\text { Risk } \\
\text { premium }\end{array}$ & $\begin{array}{c}-0.005127 \\
(-4.156966)\end{array}$ & $\begin{array}{c}1.000641 \\
(5149.240)\end{array}$ & $(3.297231)$ & $\begin{array}{l}-1.960204 \\
(-510.5486)\end{array}$ & \\
\hline CCR & $\begin{array}{l}\text { Actual } \\
\text { 3-month } \\
\text { T-bill yield }\end{array}$ & $\begin{array}{l}\text { Forward } \\
\text { interest rate } \\
\text { Risk } \\
\text { premium } \\
\end{array}$ & $\begin{array}{c}-0.248289 \\
(-4.471355)\end{array}$ & $\begin{array}{c}1.022866 \\
(106.5503)\end{array}$ & (2.381948) & $\begin{array}{c}-0.719034 \\
(-9.444820)\end{array}$ & \\
\hline $\operatorname{ARDL}(4,4)$ & $\begin{array}{l}\text { 3-month yield } \\
\text { rolled over }\end{array}$ & $\begin{array}{l}\text { 6-month } \\
\text { T-bill yield }\end{array}$ & $\begin{array}{c}0.000860 \\
(4.004321) \\
\end{array}$ & $\begin{array}{c}0.985052 \\
(88.84278) \\
\end{array}$ & $(-1.34812)$ & & $\begin{array}{l}\text { F-bounds test: } \\
11.92778(<1 \%)\end{array}$ \\
\hline $\begin{array}{l}\text { OLS with } \\
\text { HAC } \\
\text { correction }\end{array}$ & $\begin{array}{l}\text { 3-month yield } \\
\text { rolled over }\end{array}$ & $\begin{array}{l}\text { 6-month } \\
\text { T-bill yield }\end{array}$ & $\begin{array}{c}-0.000563 \\
(-1.694855)\end{array}$ & $\begin{array}{c}1.000495 \\
(51.93703\end{array}$ & $(0.025696)$ & & $\begin{array}{l}\text { Engle-Granger: } \\
0.0000 \\
\text { Phillips-Ouliaris: } \\
0.0000\end{array}$ \\
\hline FMOLS & $\begin{array}{l}\text { 3-month yield } \\
\text { rolled over }\end{array}$ & $\begin{array}{l}\text { 6-month } \\
\text { T-bill yield }\end{array}$ & $\begin{array}{c}-0.000811 \\
(-4.238137) \\
\end{array}$ & $\begin{array}{c}1.011841 \\
(151.2093) \\
\end{array}$ & $(1.769565)$ & & \\
\hline DOLS & $\begin{array}{l}\text { 3-month yield } \\
\text { rolled over }\end{array}$ & $\begin{array}{l}\text { 6-month } \\
\text { T-bill yield }\end{array}$ & $\begin{array}{c}-0.000918 \\
(-6.370652) \\
\end{array}$ & $\begin{array}{c}1.016547 \\
(201.3735) \\
\end{array}$ & (3.277883) & & \\
\hline$\overline{C C R}$ & $\begin{array}{l}\text { 3-month yield } \\
\text { rolled over }\end{array}$ & $\begin{array}{l}\text { 6-month } \\
\text { T-bill yield }\end{array}$ & $\begin{array}{c}-0.000810 \\
(-4.212106) \\
\end{array}$ & $\begin{array}{c}1.011793 \\
(150.5571) \\
\end{array}$ & $(1.754765)$ & & \\
\hline
\end{tabular}

Notes: T-statistics in parentheses. The actual risk premium is equal to the annualized margin between the 
6-month yield minus and the 3-month yield rolled over one additional quarter.

The second panel shows the results of regressing the actual T-bill yield on the forward rate and on the rolling premium, defined as the difference between the holding return for a 6-month investment and the ex post holding return of the quarterly T-bill yield, rolled over another 3 months. Since this difference is found to be stationary it is included in the ARDL specification as a fixed regressor, in contrast to the forward rate which is included as a dynamic regressor. Moreover the rationale in including this fixed regressor is by assuming perfect foresight. Later this assumption will be relaxed. This rolling premium enters significantly in all 5 estimation techniques mentioned above. The actual t-statistics are -18.0043 (ARDL), -4.2847 (OLS), -11.2774 (FMOLS), -510.548 (DOLS), and -9.4448 (CCR). Given that the sample is large these t-statistics can be compared to the z-statistics of a standard normal table. The coefficient on the ex post variable risk premium, that is included in the regressions, is close to -0.72 for three estimates (OLS, FMOLS, CCR), a bit higher at -0.4909 (ARDL), and much higher at -1.9602 (DOLS). These results ascertain that there is a statistically significant time-variable premium. This should not obscure the fact that there is also a constant risk premium of -0.25 (FMOLS, CCR). The other three estimates are outliers. For example the ARDL technique implies a positive time-variable risk premium, the DOLS implies a small and negative premium, and the OLS technique implies a coefficient of -0.1225 . The slope on the forward rate is close to +1 but is significantly higher than +1 for three techniques (FMOLS, DOLS, CCR) and no different from +1 for the remaining techniques (ARDL and OLS). Although the results produce statistical significance the finding that the slope on the forward rate is different from +1 casts doubts on the model, unless if the variable risk premium is a function of the forward rate. Incidentally the F-bounds cointegration test, the Engle-Granger residual-based test and the Phillips and Ouliaris residual-based test, all three reject the null of no cointegration at very low marginal significance levels.

The third panel consists of the results of regressing the holding period for a 3 -month investment rolled over another three months, on the holding return over 6 months. The choice of the first holding period return from rolling over the 3-month investment as the dependent variable is dictated by the fact that the second holding period return, the yield on a 6-month T-bill, is known for sure and in advance. This does not apply to the rolled over investment. The 5 regressions purport to find out whether the rational expectations assumption holds in the sample. If it does then the constant should be statistically insignificant and the slope no different from +1 . The estimates of the constant are economically minute since they vary between 0.00112 and 0.00184 or between 0.112 and 0.184 basis points per annum. There is one outlier (ARDL). The slopes are all close to +1 , but are estimated to be higher than +1 in 3 cases (FMOLS, DOLS, CCR) and equal to +1 in two cases (ARDL, and OLS). The high precision in the estimators explains the finding of statistically significant results. But economically the rational expectations hypothesis is given some support. Finally the F-bounds cointegration test, the Engle-Granger residual-based test and the Phillips and Ouliaris residual-based test, all three reject the null of no-cointegration at very low marginal significance levels.

Table 2 is also about level regressions. The panel has five parts similar to the five parts in Table 1 . The model in all parts is a level regression between the actual 3-month T-bill rate on the forward rate with the inclusion of a time-variable risk premium. Instead of taking the actual ex post risk premium and assuming perfect foresight, the risk premium is modeled as an $\operatorname{ARIMA}(1,0,1)$ process. The fitted value from this Box-Jenkins model is the second variable in the regressions. The ARIMA model is as follows with actual two-tailed p-values in parentheses:

$$
\hat{y}=0.111538(0.0054)+0.629063 \operatorname{ar}(1)(0.000)+0.496544 m a(1)(0.000)
$$

The 5 regression techniques produce the following. First, what is surprising is that the constants of the regressions take both positive and negative values which happen to be statistically very significant. Although the slope on the forward rate is very close to +1 it is estimated to be significantly higher than +1 . From these results one cannot judge whether any theory is verified. However the evidence for cointegration is strong. The F-bounds test has an actual F-value of 36.63, a value which implies a statistical significance well below the critical value of $1 \%$. The Engle-Granger residual-based tests are also supportive of cointegration. While one finds a bias in the slope of the forward rate, it is the slope of the time-variable expected risk premium that is crucial. The estimated slopes are all negative, as expected, and highly significant statistically.

Table 3 provides for a measure of the constant risk premium by regressing the spread between the actual 3-month T-bill rate and the forward rate, on a constant. There are three procedures that correct for autocorrelation and heteroscedasticity: OLS, OLS with White-Hinkley standard errors, and OLS with Newey-West standard errors. The estimates are all the same, obviously, but the statistical significance varies. It is 0.0000 for the first two procedures and 0.0074 for the third one. This confirms that the constant risk premium is negative, as 
expected, and equal to -0.2157 , or -21.57 basis points.

Table 2. Level regressions with the inclusion of the expected risk premium, modeled as an ARIMA(1,0,1) process

\begin{tabular}{|c|c|c|c|c|c|c|c|}
\hline $\begin{array}{l}\text { Econometric } \\
\text { procedure }\end{array}$ & $\begin{array}{l}\text { Dependent } \\
\text { variable }\end{array}$ & $\begin{array}{l}\text { Independent } \\
\text { variable(s) }\end{array}$ & constant & slope & Slope $=1$ & $\begin{array}{l}\text { Coefficient } \\
\text { on risk } \\
\text { premium }\end{array}$ & $\begin{array}{l}\text { Cointegration } \\
\text { test(s) }\end{array}$ \\
\hline ARDL $(2,0)$ & $\begin{array}{l}\text { Actual } \\
\text { 3-month } \\
\text { T-bill yield }\end{array}$ & $\begin{array}{l}\text { Forward } \\
\text { interest rate } \\
\text { Risk } \\
\text { premium }\end{array}$ & $\begin{array}{c}0.201618 \\
(1.839703)\end{array}$ & $\begin{array}{c}0.984900 \\
(60.28503)\end{array}$ & $(-0.924282)$ & $\begin{array}{c}-0.770365 \\
(-21.73413)\end{array}$ & $\begin{array}{l}\text { F-bounds test: } \\
36.63099(<1 \%)\end{array}$ \\
\hline $\begin{array}{l}\text { OLS with } \\
\text { HAC } \\
\text { correction }\end{array}$ & $\begin{array}{l}\text { Actual } \\
\text { 3-month } \\
\text { T-bill yield }\end{array}$ & $\begin{array}{l}\text { Forward } \\
\text { interest rate } \\
\text { Risk } \\
\text { premium }\end{array}$ & $\begin{array}{c}-0.060539 \\
(-1.121189)\end{array}$ & $\begin{array}{c}0.998813 \\
(66.32331)\end{array}$ & $(-0.078832)$ & $\begin{array}{c}-1.355948 \\
(-4.284654)\end{array}$ & $\begin{array}{l}\text { Engle-Granger: } \\
0.0000 \\
\text { Phillips-Ouliaris: } \\
0.0000 \\
\end{array}$ \\
\hline FMOLS & $\begin{array}{l}\text { Actual } \\
\text { 3-month } \\
\text { T-bill yield }\end{array}$ & $\begin{array}{l}\text { Forward } \\
\text { interest rate } \\
\text { Risk } \\
\text { premium }\end{array}$ & $\begin{array}{c}-0.180483 \\
(-3.966654)\end{array}$ & $\begin{array}{c}1.021064 \\
(129.8301)\end{array}$ & $(2.678350)$ & $\begin{array}{c}-1.356389 \\
(-21.23190)\end{array}$ & \\
\hline DOLS & $\begin{array}{l}\text { Actual } \\
\text { 3-month } \\
\text { T-bill yield }\end{array}$ & $\begin{array}{l}\text { Forward } \\
\text { interest rate } \\
\text { Risk } \\
\text { premium } \\
\end{array}$ & $\begin{array}{c}0.067043 \\
(57.54983)\end{array}$ & $\begin{array}{c}1.000622 \\
(5789.596)\end{array}$ & $(3.596842)$ & $\begin{array}{c}-2.606393 \\
(-578.3323)\end{array}$ & \\
\hline CCR & $\begin{array}{l}\text { Actual } \\
\text { 3-month } \\
\text { T-bill yield }\end{array}$ & $\begin{array}{l}\text { Forward } \\
\text { interest rate } \\
\text { Risk } \\
\text { premium }\end{array}$ & $\begin{array}{c}-0.179845 \\
(-3.828479)\end{array}$ & $\begin{array}{c}1.021068 \\
(129.7414)\end{array}$ & (2.676999) & $\begin{array}{c}-1.363191 \\
(-9.857029)\end{array}$ & \\
\hline
\end{tabular}

Notes: T-statistics in parentheses.

Table 3. Implied estimates of the constant risk premium

\begin{tabular}{llll}
\hline & $\begin{array}{l}\text { Ordinary least } \\
\text { squares } \\
\text { (OLS) }\end{array}$ & $\begin{array}{l}\text { OLS with White-Hinkley } \\
\text { heteroscedasticity consistent } \\
\text { errors and covariance }\end{array}$ & $\begin{array}{l}\text { OLS with Newey-West heteroscedasticity and } \\
\text { standard } \\
\text { autocorrelation consistent (HAC) } \\
\text { errors and covariance }\end{array}$ \\
\hline $\begin{array}{l}\text { Constant risk } \\
\text { premium: }\end{array}$ & -0.215674 & -0.215674 & -0.215674 \\
t-statistic & -6.437827 & -6.437827 & -2.683965 \\
p-value & 0.0000 & 0.0000 & 0.0074 \\
\hline
\end{tabular}

Table 4. Implied estimates of the constant risk premium and of the coefficient on the time-variable risk premium. The variable risk premium is the fitted value of an $\operatorname{ARIMA}(1,0,1)$ model of the difference in holding returns

\begin{tabular}{|c|c|c|c|}
\hline & $\begin{array}{l}\text { Ordinary least } \\
\text { squares } \\
\text { (OLS) }\end{array}$ & 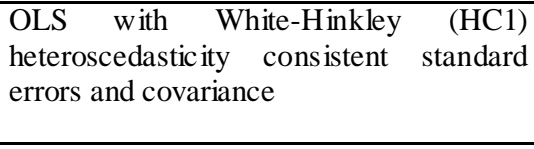 & $\begin{array}{l}\text { OLS with Newey-West heteroscedasticity and } \\
\text { autocorre lation consistent (HAC) standard } \\
\text { errors and covariance }\end{array}$ \\
\hline $\begin{array}{l}\text { Constant risk } \\
\text { premium: } \\
\text { t-statistic } \\
\text { p-value }\end{array}$ & $\begin{array}{l}-0.066288 \\
-2.312033 \\
0.0211 \\
\end{array}$ & $\begin{array}{l}-0.066288 \\
-2.076029 \\
0.0383 \\
\end{array}$ & $\begin{array}{l}-0.066288 \\
-1.918311 \\
0.0555 \\
\end{array}$ \\
\hline $\begin{array}{l}\text { Coefficient on } \\
\text { Variable risk } \\
\text { premium: } \\
\text { t-statistic } \\
\text { p-value }\end{array}$ & $\begin{array}{l}-1.356118 \\
-18.41136 \\
0.0000\end{array}$ & $\begin{array}{l}-1.356118 \\
-7.255012 \\
0.0000\end{array}$ & $\begin{array}{l}-1.356118 \\
-9.145099 \\
0.0000 \\
\end{array}$ \\
\hline $\begin{array}{l}\text { Test that } \\
\text { slope is }-1: \\
\text { Value } \\
\text { t-statistic } \\
\text { p-value }\end{array}$ & $\begin{array}{l}-0.356118 \\
-4.834839 \\
0.0000 \\
\end{array}$ & $\begin{array}{l}-0.356118 \\
-1.905173 \\
0.0572 \\
\end{array}$ & $\begin{array}{l}-0.356118 \\
-2.401511 \\
0.0166 \\
\end{array}$ \\
\hline
\end{tabular}

Table 4 takes the spread in Table 3 and regresses it on a constant and on the ARIMA expected time-variable risk premium, with the same three econometric procedures as in Table 3. The constants are now lower at -0.0663 , or -6.63 basis points, but the slopes are all higher than +1 in absolute value, and statistically significantly higher than +1 .

Table 5 is similar to Table 4 but, instead of the expected risk premium, the independent variable is the ex post risk premium. The constants are somewhat higher at -13.47 basis points, and the absolute slopes are insignificantly lower than +1 in the two regressions with adjustments of the standard errors. Because of these 
results we shall adopt the findings in Table 5 as those that are applicable. Therefore the conclusion is that the forward rate is an unbiased predictor of the future rate, with the addition of a constant and a time-variable risk premium. The constant is -13.47 basis points as already mentioned, and the mean effect of the ex post time-variable risk premium is an additional -8.11 basis points, giving a total average risk premium of 21.58 basis points. This is on the upper side of the actual historical premium between the 6 and 3-month investment of 14 basis points. This variable risk-premium has a maximum of 184.6 basis points, and a minimum of -123.2 basis points. If one takes the median estimate the time-variable risk premium averages 5.15 basis points, making a total of 18.62 basis points. Given the small-sample bias and the presence of sampling errors such an estimate mirrors a satisfactory achievement to explain the average risk premium. It must be noted that the actual historical risk premium of 14 basis points is the spread between 6 and 3 -month investments, while the risk premium estimated in this paper is between the expected 3-month interest rate and the 3-month forward rate. Therefore hedging in forward markets carries an additional risk premium that speculators are likely to require.

Table 5. Implied estimates of the constant risk premium and the coefficient on the time-variable risk premium The variable risk premium is the difference in holding returns

\begin{tabular}{|c|c|c|c|}
\hline & $\begin{array}{l}\text { Ordinary least } \\
\text { squares } \\
\text { (OLS) }\end{array}$ & $\begin{array}{l}\text { OLS with White-Hinkley } \quad \text { (HC1) } \\
\text { heteroscedasticity consistent } \\
\text { errors and covariance }\end{array}$ & $\begin{array}{l}\text { OLS with Newey-West heteroscedastic ity and } \\
\text { autocorre lation consistent (HAC) standard } \\
\text { errors and covariance }\end{array}$ \\
\hline $\begin{array}{l}\text { Constant risk } \\
\text { premium: } \\
\text { t-statistic } \\
\text { p-value }\end{array}$ & $\begin{array}{l}-0.134712 \\
-4.217893 \\
0.0000 \\
\end{array}$ & $\begin{array}{l}-0.134712 \\
-3.760049 \\
0.0002\end{array}$ & $\begin{array}{l}-0.134712 \\
-3.096866 \\
0.0020\end{array}$ \\
\hline $\begin{array}{l}\text { Coefficient } \\
\text { on Variable } \\
\text { risk premium: } \\
\text { t-statistic } \\
\text { p-value }\end{array}$ & $\begin{array}{l}-0.736609 \\
-4.834440 \\
0.0000 \\
\end{array}$ & $\begin{array}{l}-0.736609 \\
-3.753523 \\
0.0002 \\
\end{array}$ & $\begin{array}{l}-0.736609 \\
-4.834440 \\
0.0000 \\
\end{array}$ \\
\hline $\begin{array}{l}\text { Test that } \\
\text { slope is }-1 \text { : } \\
\text { Value } \\
\text { t-statistic } \\
\text { p-value }\end{array}$ & $\begin{array}{l}0.263391 \\
3.851499 \\
0.0001\end{array}$ & $\begin{array}{l}0.263391 \\
1.342153 \\
0.1800\end{array}$ & $\begin{array}{l}0.263391 \\
1.728658 \\
0.0843\end{array}$ \\
\hline
\end{tabular}

Exhibit 1 depicts the total risk premium, in which the time-variable risk premium is added to the constant risk premium. The graph shows very high volatility, but this is just due to the fact that the graphed series is blown out of proportion. The actual risk premium varies in a close bracket, between $-1 \%$ and $+2 \%$, and this is only at times of high turmoil in financial markets (the early 1980s). Most of the variation is centered at $0.25 \%$, or 25 basis points. However, one cannot ignore the visual evidence that the risk premium has moved in clusters, implying the existence of serial correlation and conditional heteroscedasticity. This is confirmed by the Ljung-Box Q-statistics.

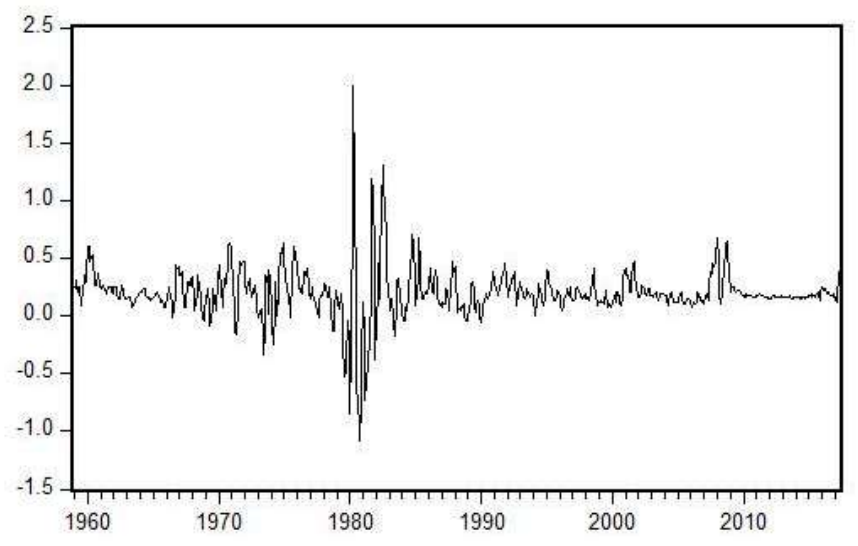

\section{Conclusion}

Exhibit 1. Total risk premium

This paper studies the relation of unbiasedness between the 3-month forward interest rate, derived from US T-bills, and the 6-month US T-bill interest rate. Risk neutrality, forward market efficiency, and unbiasedness are 
rejected in our sample. This implies the existence of risk premiums. There is strong evidence for a constant risk premium and a time-variable risk premium. The constant risk premium averages 13.47 basis points and the average of the time-variable premium is 8.11 basis points, making a total of 21.58 basis points. The time-variable risk premium ranges between a maximum of 184.6 basis points, and a minimum of -123.2 basis points. If one takes the median estimate the time-variable risk premium averages 5.15 basis points, making a total of 18.62 basis points Therefore hedging by forward rates is not risk-neutral, or, else, forward transactions carry a certain risk. Although this risk premium is small, i.e. is less than $1 \%$, it is still highly significant statistically. The results contradict the notion that the short end of the interest rate market is practically riskless. An avenue for future research is by studying other maturities. The methodology in this paper is appropriate for that purpose, and little is needed to adapt it.

\section{References}

Al-Zoubi, H. A. (2011). A new look at the forward premium "puzzle". Journal of Futures Markets, 31(7), 599-628. https://doi.org/10.1002/fut.20486

Azar, S. A. (2018) The pure expectations theory and quarterly interest rate premiums. Accounting and Finance Research, 7, 1, 161-178. https://doi.org/10.5430/afr.v7n1p161

Baillie, R. T., and Bollerslev, T. (1989). Common stochastic trends in a system of real exchange rates. Journal of Finance, 444, 167-181. https://doi.org/10.1111/j.1540-6261.1989.tb02410.x

Bekaert, G., \& Hodrick, R. J. (2001). Expectations hypotheses tests. The Journal of Finance, 56(4), 1357-1394. https://doi.org/10.1111/0022-1082.00371

Campbell, J. Y., \& Shiller, R. J. (1987). Cointegration and tests of present value models. Journal of political economy, 95(5), 1062-1088. https://doi.org/10.1086/261502

Campbell, J. Y., \& Shiller, R. J. (1991). Yield spreads and interest rate movements: A bird's eye view. The Review of Economic Studies, 58(3), 495-514. https://doi.org/10.2307/2298008

Choi, S., \& Wohar, M. E. (1991). New evidence concerning the expectations theory for the short end of the maturity spectrum. Journal of Financial Research, 14(1), 83-92. https://doi.org/10.1111/j.1475-6803.1991.tb00646.x

Fama, E. F. (1984). Forward and spot exchange rates. Journal of Monetary Economics, 14(3), 319-338. https://doi.org/10.1016/0304-3932(84)90046-1

Finlay, R., \& Jones, C. (2011). Time-varying term premia and the expectations hypothesis in Australia. Applied Economics Letters, 18(2), 133-136. https://doi.org/10.1080/13504850903508259

Fisher, I. (1930). The Theory of Interest. New York: McMillan Press.

Hall, A. D., Anderson, H. M., \& Granger, C. W. (1992). A cointegration analysis of treasury bill yields. The review of Economics and Statistics, 116-126. https://doi.org/10.2307/2109549

Hatemi-J, A., \& Roca, E. (2012). A re-examination of the unbiased forward rate hypothesis in the presence of multiple unknown structural breaks. Applied Economics, 44(11), 1443-1448. https://doi.org/10.1080/00036846.2010.543075

Hejazi, W., Lai, H., \& Yang, X. (2000). The expectations hypothesis, term premia, and the Canadian term structure of interest rates. Canadian Journal of Economics/Revue canadienne d'économique, 33(1), 133-148. https://doi.org/10.1111/0008-4085.00009

Kellard, N., Newbold, P., \& Rayner, T. (2001). Evaluating currency market efficiency: are cointegration tests appropriate? Applied Financial Economics, 11(6), 681-691 https://doi.org/10.1080/09603100010023113

Keynes, J. M. (1930). A Treatise on Money. London: McMillan Press.

Konstantinou, P. T. (2005). The expectations hypothesis of the term structure: a look at the Polish interbank market. Emerging Markets Finance and Trade, 41(3), 70-91.

Kwiatkowski, D., Phillips, P. C., Schmidt, P., \& Shin, Y. (1992). Testing the null hypothesis of stationarity against the alternative of a unit root: How sure are we that economic time series have a unit root? Journal of Econometrics, 54(1-3), 159-178. https://doi.org/10.1016/0304-4076(92)90104-Y

Longstaff, F. A. (2000). The term structure of very short-term rates: New evidence for the expectations hypothesis. Journal of Financial Economics, 58(3), 397-415.

https://doi.org/10.1016/S0304-405X(00)00077-5 
MacDonald, R. (1988) Floating Exchange Rates Theories and Evidence, London, Unwin Hyman. https://doi.org/10.4324/9780203427484

McMillan, D. G. (2005). Cointegrating behaviour between spot and forward exchange rates. Applied Financial Economics, 15(16), 1135-1144. https://doi.org/10.1080/09603100500359476

Mills, T. C., \& Markellos, R. N. (2008). The Econometric Modelling of Financial Time Series. 2nd edition, Cambridge: Cambridge University Press. https://doi.org/10.1017/CBO9780511817380

Newey, W. K., \& West, K. D. (1987). A simple, positive semi-definite, heteroskedasticity and autocorrelation consistent covariance matrix.

Sarno, L., Thornton, D. L., \& Valente, G. (2007). The empirical failure of the expectations hypothesis of the term structure of bond yields. Journal of Financial and Quantitative Analysis, 42(1), 81-100. https://doi.org/10.1017/S0022109000002192

Sarno, L., Valente, G., \& Leon, H. (2006). Nonlinearity in deviations from uncovered interest parity: an explanation of the forward bias puzzle. Review of Finance, 10(3), 443-482. https://doi.org/10.1007/s10679-006-9001-z

Shiller, R. (1989). Market Volatility MIT Press. Cambridge Mass. PMid:2930638

Strohsal, T., \& Weber, E. (2014). Mean-variance cointegration and the expectations hypothesis. Quantitative Finance, 14(11), 1983-1997. https://doi.org/10.1080/14697688.2013.814974

Suardi, S. (2010). Nonstationarity, cointegration and structural breaks in the Australian term structure of interest rates. Applied Economics, 42(22), 2865-2879. https://doi.org/10.1080/00036840801964625

Thornton, D. L. (2005). Tests of the expectations hypothesis: Resolving some anomalies when the short-term rate is the Federal Funds rate. Journal of Banking and Finance, 29, 2541-2556. https://doi.org/10.1016/j.jbankfin.2004.09.005

Thornton, D. L. (2006). Tests of the expectations hypothesis: resolving the Campbell-Shiller paradox. Journal of Money, Credit and Banking, 511-542. https://doi.org/10.1353/mcb.2006.0036

Verbeek, M. (2012). A Guide to Modern Econometrics. 4th edition, Wiley.

\section{Copyrights}

Copyright for this article is retained by the author(s), with first publication rights granted to the journal.

This is an open-access article distributed under the terms and conditions of the Creative Commons Attribution license (http://creativecommons.org/licenses/by/4.0/). 